\title{
Core Binding Factor Complex Mutation
}

National Cancer Institute

\section{Source}

National Cancer Institute. Core Binding Factor Complex Mutation. NCI Thesaurus. Code C129409.

Mutations in the genes that encode proteins found in the core binding factor (CBF) complex. These genes may be involved in chromosomal rearrangements that are associated with acute myeloid leukemia. 